\title{
Man Anxiety as Reflected in Ernest Hemingway's The Old Man and the Sea
}

\author{
Dania Musoffa, Akhmad Multazim, Atikasari Husna, Lutfy F. Hudayah \\ \& Renovil Dramestika \\ daniamusoffa@gmail.com, jaymultazim@gmail.com, atikasari.husna@gmail.com, \\ lutfyfajarhudayah@gmail.com, renovildramestika@gmail.com \\ Department of English Education, Universitas Ahmad Dahlan
}

\begin{abstract}
In modern era, problems occur continuously and it triggers stress and anxiety. This study aims to describe characterization and the anxiety of the main character in 'The Old Man and The Sea', a novel by Ernest Hemingway. This studybelongs to library research that applied descriptive qualitative method with psychological approach. Reading and documentation techniques were used to collect the data. To analize the anxiety of the main character, a theory on psychological anxiety by Durand and Barlow were used. The result shows that: 1) the main character, Santiago, is described as a man who is kind, industrious, ambitious, powerful, smart, calm, cheerful, patient, confident and stubborn, 2) the anxieties felt by Santiago are Generalized Anxiety Disorder (GAD), Panic Disorder, Specific Phobia, Post-Traumatic Stress Disorder (PTSD) and Obsessive-Compulsive Disorder (OCD).
\end{abstract}

Keywords: anxiety, Ernest Hemingway, psychological approach

\section{Background}

Emotion is a feeling that can give more affect to our behavior. It can cause the people recognize many kinds of expressions, for example, sad, angry, happy, anxiety, etc. Anxiety is a common feeling that can be felt by human being. It can be signed by sensation of horror or mental stress and followed by withdrawal reaction or escape reaction. It can be caused by bad experience or traumatic events. Customs, imitation and memories of the bad experiences are important influences that cause anxiety such as stories, pictures, radio, and TV program, and movie which are terrifying (Hurlock, 1980).

Anxiety may also appear in literary work. One of the authors who write much about anxiety condition is Ernest Hemingway. Ernest Hemingway was born in Oak Park, Illionis. He is one of the best selling authors in the United
State and around the world. He had written many novels and he had written many books based on his real-life experiences. His father was a doctor and his mother was a singer and music teacher. Hemingway's life was influenced by his father's life. He was fond of the masculine life of sport and hardship. He rejected the possibility of college education after leaving school. He was involved in the medical grounds for active service in world war I in 1917. He became a newspaper reporter in Kansas City. Then, he became an ambulance driver with the Red Crodd in Italy. During world war I, together with his success to win a medal, and his unsuccessful love-affair was expressed in his novel A Farewell to Arms.

The Old Man (Santiago), with litle sleep and food, endured much pain. On the third day at sea, he succeeded in drawing the weakened marlin to the surface, and harpooned it. The fish was so big that it could not be pulled into 
the boat, and had to be lashed along side. While Santiago was trying hard to pull the fish to the harbour, sharks attacked to eat the fish all night. Reaching the harbour, the old man found that only the giant skeletone of the fish left. The novel shows that the old man won the struggle but he also lost what he fought for and won. Anyway, the old man's struggle should be respected.

At least, The Old Man and The Sea is a novel which contains a lot of expressions, such as anger, happiness or anxiety expression. The writer is specially interested to investigate the anxiety expression which exists in the "The Old Man and The Sea" by Ernest Hemigway.

The study on characterization has been discussed by Abdul Hameed Panhwar, Sanaullah Ansari, Muhammad Hassan Khoso (2017). This study reveals the character of Edna in Kate Chopin's novel by interpreting multilayered personality of Edna by seeing the realtionship of Edna with other characters and how it impacts Edna's mind. The result proves that Edna has controversial inter-personal relationships in which Edna is strong-willed and ostentatious, independent, resists societal challenges and familial constraints.

This study focused on library research dealing with psychological approach to investigate the character and characterization and also the anxiety of main character to reveal social phenomenon on psychology inside a literary work.

\section{Character and Characterization}

Character may be thought of as behaving in accordance with social expectancies (Stagner, 1965). According to Subhan (2006), characters in the novel can be divided into two groups. They are main character and minor character.

\section{a. Character}

According to Subhan (2006), characters in a literary work can be divided into two groups, major or main character and minor character. The major character can further be analyzed into three groups; 1) the protagonist, 2) the antagonist, and 3) the companion.

\section{1) Protagonist}

Protagonist character is the main character, the leading actor (actress). He or she is usually the hero/heroine that plays an important role in the story. The protagonist character in the novel can be identified by:

a) His/her position in the story.

b) His/her frequent appearance in the story.

c) The title of the novel simply represents the name of the protagonist.

In the modern novel or the absurd novel, protagonist can act evil, grotesque or crazy, a villain, and a rogue. If it happens, the protagonist character would oppose the antagonist character who is good; or in other words, a character having integrated personality and trusted responsible character.

\section{2) Antagonist}

The antagonist in the novel usually refers to the enemy of the protagonist. In the didactic novel, or in the novel in which there is an element of moral teaching, the antagonist character is usually immoral or evil because the protagonist is usually good or true.

\section{3) Companion}

The companion is usually the supporter or the partner of the protagonist. The companion of the protagonist may function as a lover of the protagonist. The companion of the protagonist also plays as an important role in the story. In this research, the researcher presents the major character besides of the minor character.

\section{b. Characterization}

According to Minderop (2005), characterization means character portrayal. Characterization method in the research of literary work is the method that describes the nature of the figures contained in a work of fiction. The way to determine the character in this case is imaginative character and determine the nature character that is different.

According to Subhan (2005), character in the novel can be divided into two groups: 


\section{1) Flat character}

A character in the novel is said to be flat when he or she has an unchanging characteristic from the beginning to the end of the story. It means his/her character is strong and monotone personality to show the characteristics himself/herself.

\section{2) Round character}

In contrast to the description of the flat character, a round character is one which undergoes changes in the characterization in the course of the story. The reason is that the character undergoes changes in the characterization in the course of the story. In the same way, a character is said to be round when he/she is bad in the beginning and then becomes good in the middle or in the end of the story.

\section{Anxiety}

Anxiety is a feeling of nervousness, apprehension, fear, or worry. Some fears and worries are justified, such as worry about a loved one or in anticipation taking a quiz, test, or other examination. Anxiety problem interferes with the sufferer's ability to sleep or otherwise function. It is noteworthy that teenagers are particularly susceptible to having irritability as a symptom of a number of emotional problems, including anxiety. Anxiety may occur without a cause, or it may occur based on a real situation but may be out of proportion to what would normally be expected. Severe anxiety can have a serious impact on daily life.

In psychological contributions, Durand (2002) says that anxiety as a psychological reaction for the dangers in childhood period. In childhood we may gain awareness that we cannot control all events, which can influence our feeling in the danger. We can actually fail in everything if we are anxious to do. While in social contribution is stress. It is because of individual problems or social pressure in live. There are several types of anxiety, they are:

\section{a. Generalized Anxiety Disorder}

This a common condition. The disorder is characterized by excessive anxiety and worry that is out of proportion to the impact of the event or circumstance that is the focus of the worry. Persons with GAD may eventually experience other mental disorders, such as panic disorder or major depressive disorder. They may feel restless, fatigued, easily distracted, or have trouble falling asleep. Someone with GAD also cannot relax and always feel tense and on edge. GAD often occurs with other problems such as depression or other anxiety disorder.

\section{b. Panic Disorder}

Unpredictable attacks of anxiety are accompanied by physiological manifestations. People with this disorder often undergo medical evaluations for symptoms related to heart attacks or other medical conditions before the diagnosis of panic disorder is made. Attacks may last from minutes to hours. An affected person often lives in fear of another attack and may be reluctant to be alone or far from medical assistance. Panic attacks can occur at any time, even during sleep. An attack generally peaks within 10 minutes, but some symptoms may last much longer.

\section{c. Specific Phobia}

A specific phobia is an extreme or unreasonable feeling of fear or anxiety linked to a specific animal, object, activity, or situation. For a specific disorder to be diagnosed, the person must experience extreme distress and an impairment in normal functioning. Specific phobias can begin in childhood. Although there are many possible phobic targets, majority of kids and teens fear the same types of objects or events such as height, bugs, or needles.

\section{d. Social Anxiety Disorder}

Social anxiety disorder is characterized by an extreme fear of being embarrassed, ridiculed, or humiliated in public. The fear and worry can begin days or even weeks before the social situation. Doctors place social anxiety disorder in two categories. One type involves more specific fears that are limited in performance situation, such as having to read aloud in class. The second category is more general, and refers to anxiety that occurs in 
social settings, like lunchtime in the cafeteria, gym class, or parties. The more general form usually begins earlier in life and can last for a longer time.

\section{e. Post-Traumatic Stress Disorder}

Post-Traumatic Stress Disorder is the result of exposure to a traumatic event. Trauma such as physical abuse or rape, interpersonal or community violence, serious accidents, or illnesses may spark PostTraumatic Stress Disorder.

Post - Traumatic Stress Disorder causes certain types of symptoms. Teens may have random flashbacks or recurring dreams, where they feel like they are re-experiencing the traumatic event. They may avoid any event or place associated with the trauma, or feel numb. Some teens may feel jittery or irritable, be startled easily, and have difficulty falling asleep.

\section{f. Obsessive-Compulsive Disorder (OCD)}

OCD involves irrational behavior that interferes with normal life. For example, it may take the young person hours to get ready for school and can lead them to be late or miss school. Or it may take a lot of time to finish schoolwork because the teen feels as if she has to rewrite an assignment over and over again to get it just right. People with OCD sometimes exhibit ties (like twitches and spasms) and attention deficit hyperractivity disorder (ADHD).

\section{Psychological Approach}

According to Warren and Wellek (1978), the most important thing of literary work can be seen as good writing if a product of the author has creative "clever" (or gifted or talented) and having mush knowledge and experience". By using those factors, an author can produce a good literary work which is monumental and able to cross the border of space and time. By "Psychology of Literature" mean the psychological study of the writer, as type and as individual, or the study of the creative process, or the study of the psychological types and laws present within works of literature, or, finally, the effect of literature upon its readers (audience psychology.

There are some definitions about psychological approach. According to Subhan (2005), psychological approach has a view that psychology (the science or study of mind and its processes) can be used to help a literary critic or a literary researcher to explain, interpret, and evaluate literary works. Psychology stems from the Greek word meaning "mind" and "study", and the systematic study of mind began, as did most of Western philosophy, during the Golden Age of Greece. As Greek philosophy thrived, so did psychology, but it was, and remained, a speculative endeavor, heavily dependent upon mystical or religious interpretations. (Moskowitz and Orgel, 1969)

Psychology is the scientific study of behavior and the mind. This definition contains three elements. First, psychology is a scientific enterprise that obtains knowledge through systematic and objective methods of observation and experimentation. Second, psychology studies behavior, which refer to any action or reaction that can be measured such as the blink of an eyes, an increase in heart rate, or the unruly violence that often erupt in mob. Third, psychologies study of the main, which refers to both conscious mental.

According to Subhan (2003), the psychological study of the writer is as type and as individual. $\mathrm{He}$ also concludes that psychological approach can be used to conduct a study about creative process. This writing can conduct a study about creative process. This writing can conduct about the process of making literary work using the psychological approach, writer can find out the way of literary work is made into being by its author. Psychological approach can be used to conduct a study about the psychological aspect of the literary works and also in value and role. He also says that the study of psychological types and laws present within works of literature. 


\section{Research Method}

This research employed descriptive qualitative method. It applied psychological approach. The primary source of the data was the novel The Old Man and The Sea by Ernest Hemingway and the secondary data was from other sources like articles, books and internet sources. To collect the data, it used note-taking and documentation technique and to analyze the data, a theory on psychological anxiety by Durand and Barlow (2006) supported by Wellek and Warren (1978) was used.

\section{Discussion}

\section{Character and Characterization}

The main character in this novel is Santiago (The Old Man). The description of characterization.

\section{a. Kind}

Santiago has a kind character in his life; he can make a good relationship with other people and he can also help the people who need his hand. Santiago is kind and compassionate; humility is always shown everywhere.

"Thank you," the old man said. He was too simple to wonder when he had attained humility. But he knew he had attained it and he knew it was not disgraceful and it carried no loss of true pride. (Hemingway: 3)

It means that Santiago has heart which is kind. He always thanks in everything and then always feels lowly. Santiago has high empathy. The statement can be seen from quotation below:

"The old man looked at him with his sunburned, confident loving eyes.

"If you were my boy I'd take you out and gamble," he said. "But you are your father's and your mother's and you are in a lucky boat." (Hemingway: 3)

From the quotation above, the researcher knows that Santiago is a kind person; he always cares with everyone who loves him. He gives attention to Manolin like his child. Santiago always gives the best for him. He cares toward the other people.

\section{b. Industrious}

Santiago is an industrious. He always tries to make his life better. The statement can be seen from quotation below:

"Some time before daylight something took one of the baits that were behind him. He heard the stick break and the line begin to rush out over the gunwale of the skiff. In the darkness he loosened his sheath knife and took all the strain of the fish on his left shoulder; he leaned back and cut the line against the wood of the gunwale. Then he cut the other line closest to him and in the dark made the loose ends of the reserve coils fast. He worked skillfully with the one hand and put his foot on the coils to hold them as he drew his knots tight. Now he had six reserve coils of line. There were two from each bait, he had severed and the two from the bait the fish had taken and they were all connected. (Hemingway: 18)

It means that Santiago is always effective and skillful in his work. He uses his mind and his power when he works. In the other statement, Santiago also shows how his efforts (work) do. The other statement is to substantiate this argument:

You have only yourself and you had better work back to the last line now, in the dark or not in the dark, and cut it away and hook up the two reserve coils.

So he did it. It was difficult in the dark and once the fish made a surge that pulled him down on his face and made a cut below his eye. The blood ran down his cheek a little way. But it coagulated and dried before it reached his chin and he worked his way back to the bow and rested against the wood. He adjusted the sack and carefully worked the line so that it came across a new part of his shoulders and, holding it anchored with his shoulders, he carefully felt the pull of the fish and then felt with his hand the progress of the skiff through the water. (Hemingway: 19) 
From the quotation above, it proves that Santiago is an industrious. He works very hard in order to make their life better. He learns everything quickly to make him easy to work.

\section{c. Ambitious}

Santiago has an ambitious character and he will prove to the other man that he can get fish. He devotes his life to cathc Marlin. The statement can be seen from quotation below:

"I'll kill him though," he said. "In all his greatness and his glory."

Although it is unjust, he thought. But I will show him what a man can do and what a man endures.

"I told the boy I was a strange old man," he said.

"Now is when I must prove it." (Hemingway: 24)

From the quotation above, Santiago shows that he ambitious to get what he wants. He will get it and prove for the other people. He will get back his greatness and his glory.

\section{d. Powerful}

Santiago is a powerful man. The statement can be seen from quotation below:

"I can remember the tail slapping and banging and the thwart breaking and the noise of the clubbing. I can remember you throwing me into the bow where the wet coiled lines were and feeling the whole boat shiver and the noise of you clubbing him like chopping a tree down and the sweet blood smell all over me." (Hemingway: 2)

From the quotation above, the researcher knows that Santiago is strong. It can be seen from how Santiago kills the fish. He does that powerfully, that make Manolin (his friend) overawe for him. The other statement that can give corroboration can be seen in this quotation:

The boy took the old army blanket off the bed and spread it over the back of the chair and over the old man's shoulders. They were strange shoulders, still powerful although very old, and the neck was still strong too and the creases did not show so much when the old man was asleep and his head fallen forward. (Hemingway: 2)

From that statement, the researcher knows that Santiago is strong. He is a powerful man. He can do something which maybe anyone else can't do. He is an old man who has good power and body.

\section{e. Smart}

Santiago is a smart person. He always tries to get the best. He has a lot of ways to do his work easily. He never loses way to solve the problem. It can be seen from this quotation:

"I may not be as strong as I think," the old man said. "But I know many tricks and I have resolution." "You ought to go to bed now so that you will be fresh in the morning. I will take the things back to the Terrace." (Hemingway: 8)

The other statement that shows Santiago is smart is:

He let his hand dry in the air then grasped the line with it and eased himself as much as he could and allowed himself to be pulled forward against the wood so that the boat took the strain as much, or more, than he did. (Hemingway: 27)

From the quotation, the researcher believes that Santiago is Smart. It can be proven from how Santiago solves his problem when he is in problem. He never loses his way and has many tricks.

\section{f. Calm}

Santiago is always calm when he gets the problem. He can control his emotion. It can be seen from this quotation:

"...he seems calm, he thought, and following his plan. But what is his plan, he thought. And what is mine? Mine I must improvise to his because of his great size. If he will jump I can kill him. But he stays down forever. Then I will stay down with him forever. (Hemingway: 22) 
This quotation proves that Santiago can be calm when he is in problem, so he can think what he should do well.

\section{g. Cheerful}

Santiago is an old man who always cheerful. It can be seen from this quotation:

Everything about him was old except his eyes and they were the same color as the sea and were cheerful and undefeated. (Hemingway: 1)

That quotation shows that Santiago is an old man, but he is always cheerful. He never shows his problem to the other people although sometimes he is in trouble.

\section{h. Pateint}

Santiago is a good man. He can be patient when many people make fun of him. It can be seen from this quotation:

They sat on the Terrace and many of the fishermen made fun of the old man and he was not angry. (Hemingway: 1)

From the quotation above, the researcher knows that Santiago is a patient person. It can be proven when many people make fun of him, he is not angry and he is in face of calmly.

\section{i. Confident}

Santiago always feels himself is lucky, he always believes that he will get what he wants. He never loses his hope and confidence. It can be seen from this quotation:

"May I get the sardines? I know where I can get four baits too."

"I have mine left from today. I put them in salt in the box."

"Let me get four fresh ones."

"One," the old man said. His hope and his confidence had never gone. But now they were freshening as when the breeze rises. (Hemingway: 4)

The other statements that prove Santiago is confident are:
"Tomorrow is going to be a good day with this current," he said.

"Where are you going?" the boy asked.

"Far out to come in when the wind shifts. I want to be out before it is light." (Hemingway: 4)

Based from all statement, the researcher believes that Santiago is an old man who never loses hope and confidence. He always believes that he will get the best in the other time. He never gives up, and he always tries and tries to get the best.

\section{j. Stubborn}

Santiago is also a stubborn person. It can be seen from the quotation below:

"Wake up old man," the boy said and put his hand on one of the old man's knees. The old man opened his eyes and for a moment he was coming back from a long way away. Then he smiled. "What have you got?" he asked. "Supper," said the boy. "We're going to have supper." "I'm not very hungry."

"Come on and eat. You can't fish and not eat."

"I have," the old man said getting up and taking the newspaper and folding it. Then he started to fold the blanket. (Hemingway: 6)

The other statements:

"That's very kind of you," the old man said. "Should we eat?"

"I've been asking you to," the boy told him gently. "I have not wished to open the container until you were ready."

"I'm ready now," the old man said. "I only needed time to wash." (Hemingway: 6)

Based on all those statements, the researcher knows that Santiago is a stubborn person. He feels inferior when he is helped by people.

\section{Man Anxiety}

Anxiety is a feeling nervousness, apprehension, fear, or worry. Some fears and worries are justified, such as worry about a 
loved one or in anticipation taking a quiz, test, or other examination. Anxiety problem interferes with the sufferer's ability to sleep or otherwise function. It is noteworthy that teenagers are particularly susceptible to having irritability as a symptom of a number of emotional problems, including anxiety. Anxiety may occur without a cause, or it may occur based on a real situation but may be out of proportion to what would normally be expected. Severe anxiety can have a serious impact on daily life.

After reading the novel and learn about theory of anxiety, the researcher finds some types of anxiety that are shown by Santiago. Some of them are Generalized Anxiety Disorder (GAD), Panic Disorder, Specific Phobia, Social Anxiety Disorder, Post Traumatic Stress Disorder (PTSD), and Obsessive - Compulsive Disorder (OCD).

\section{a. Generalized Anxiety Disorder}

This a common condition. The disorder is characterized by excessive anxiety and worry that is out of proportion to the impact of the event or circumstance that is the focus of the worry. It can be seen in quotation below:

"One sheet. That's two dollars and a half. Who can we borrow that from?"

"That's easy. I can always borrow two dollars and a half."

"I think perhaps I can too. But I try not to borrow. First you borrow. Then you beg."

"Keep warm old man," the boy said. "Remember we are in September."

"The month when the great fish come," the old man said. "Anyone can be a fisherman in May."( Hemingway: 5)

The researcher finds Santiago's anxiety when the boy wants to borrow money, he feels worry about it. We can see in sentences "I think perhaps I can too. But I try not to borrow. First you borrow. Then you beg." Santiago's anxiety is the common anxiety. Everyone feels like that when borrow something. Santiago worries if he can not be responsible for what he does.

\section{b. Panic Disorder}

This is an unpredictable attack of anxiety accompanied by physiological manifestations. People with this disorder often undergo medical evaluations for symptoms related to heart attacks or other medical conditions before the diagnosis of panic disorder is made. Attacks may last from minutes to hours. The researcher finds this anxiety in this quotation:

\begin{abstract}
"Agua mala," the man said. "You whore." From where he swung lightly against his oars he looked down into the water and saw the tiny fish that were coloured like the trailing filaments and swam between them and under the small shade the bubble made as it drifted. They were immune to its poison. But men were not and when same of the filaments would catch on a line and rest there slimy and purple while the old man was working a fish, he would have welts and sores on his arms and hands of the sort that poison ivy or poison oak can give. But these poisonings from the agua mala came quickly and struck like a whiplash. (Hemingway: 12-13)
\end{abstract}

In this quotatuion, when Santiago sees "Agua mala", he feels panic, and he says bad thing. He worries when he sees it, because it is very dangerous and it is a poison that can hurt human or maybe kill human.

\section{c. Specific Phobia}

A specific phobia is an extreme or unreasonable feeling of fear or anxiety linked to a specific animal, object, activity, or situation. For a specific disorder to be diagnosed, the person must experience extreme distress and an impairment in normal functioning. It can be seen in this quotation:

The sun rose thinly from the sea and the old man could see the other boats, low on the water and well in toward the shore, spread out across the current. Then the sun was brighter and the glare came on the water and then, as it rose clear, the flat sea sent it back at his eyes so that it hurt sharply and he rowed without looking into it. He looked down into the water and watched the lines that went straight down into the dark of 
the water. He kept them straighter than anyone did, so that at each level in the darkness of the stream there would be a bait waiting exactly where he wished it to be for any fish that swam there. Others let them drift with the current and sometimes they were at sixty fathoms when the fishermen thought they were at a hundred. But, he thought, I keep them with precision. Only I have no luck any more. But who knows? Maybe today. Every day is a new day. It is better to be lucky. But I would ather be exact. Then when luck comes you are ready. (Hemingway: 11)

In that condition, Santiago feels anxiety. When the sun is brighter and the glare comes on the water and then, as it rises clear, the flat sea sends it back at his eyes so that it hurts sharply and he rows without looking into it. His experience when the sun is bright that he can't see it clearly, he always keeps with precision in this condition. He fears he will be sunlucky again. He is in worry, but he keeps his ambition to catch fish. It can be seen when he hopes he will be lucky.

\section{d. Social Anxiety Disorder}

Social anxiety disorder is characterized by an extreme fear of being embarassed, ridiculed, or humiliated in public. The fear and worry can begin days or even weeks before the socaial situation. The researhcer finds this anxiety in quotation below:

"But remember how you went eighty-seven days without fish and then we caught big ones every day for three weeks."

"I remember," the old man said. "I know you did not leave me because you doubted."

"It was papa made me leave. I am a boy and I must obey him."

"I know," the old man said. "It is quite normal."

"He hasn't much faith."

(Hemingway:1-2)

This quotation means that Santiago has bad experience in the past, while he keeps being lucky when he gets what he wants. When he says like that, he realizes that in the next journey, he will go alone without the boy (Manolin). Actually, Santiago has not much faith when he goes alone, because there is no one who can help him. While, usually, he goes with the boy and the boy always helps Santiago. In this situation, Santiago reallizes that he is an unlucky people, like the others say. So he keeps his decision to go alone without Manolin.

\section{e. Post-Traumatic Stress Disorder}

Post-Traumatic Stress Disorder is the result of exposure to a traumatic event. Trauma, such as physical abuse or rape, interpersonal or community violence, serious accidents, or illnesses, may spark PostTraumatic Stress Disorder. This anxiety can be seen in quotation below:

"Tomorrow is going to be a good day with this current," he said.

"Where are you going?" the boy asked.

"Far out to come in when the wind shifts. I want to be out before it is light."

"I'll try to get him to work far out," the boy said. "Then if you hook something truly

big we can come to your aid."

"He does not like to work too far out."

"No," the boy said. "But I will see something that he cannot see such as a bird working and get

him to come out after dolphin." "Are his eyes that bad?" "He is almost blind." "It is strange," the old man said. "He never went turtle-ing. That is what kills the eyes." "But you went turtle-ing for years off the Mosquito Coast and your eyes are good."

"I am a strange old man"

"But are you strong enough now for a truly big fish?"

"I think so. And there are many tricks." (Hemingway: 3)

It means that Santiago feels he is a strange man, he knows that when he goes alone and he goes far away, maybe he can find some problems. Actually he is in doubfulness. We can see in the sentence "I think so". In this sentence, he shows he unbelieves that he can find or get something, but he keeps trying with his doubfulness. 


\section{f. Obsessive-Compulsive Disorder}

OCD involves irrational behavior that interferes with normal life. Usually, the person suffering from OCD uses ritualistic and repeated behaviors to rid themselves of obsessive thoughts and anxieties. In the novel, the sentences that show this anxiety can be seen in quotation below:

"I could just drift, he thought, and sleep and put a bight of line around my toe to wake me. But today is eighty-five days and I should fish the day well." (Hemingway: 14)

This quotation describes that Santiago feels tired and begins to give up, but he realizes that he is still unlucky and does not get anything after eighty-five days. So he always keeps trying to catch fish altough he is very tired. His anxiety is if he goes back without fish. So he does not want to sleep and always keeps in fishing. He thinks that if he sleeps and wastes time he will be unlucky again and not get the fish.

\section{Conclusion}

This study concludes that the characterizations of Santiago are kind, industrious, ambitious, powerful, smart, calm, cheerful, patient, confident, and also stubborn.

Santiago is the main character in the novel. He has some anxieties such as Generalized Anxiety Disorder (GAD), Panic Disorder, Specific Phobia, Social Anxiety Disorder, Post - Traumatic Stress Disorder (PTSD), and Obsessive - Compulsive Disorder (OCD). However, he never gives up in his life. $\mathrm{He}$ gives realistic condition. $\mathrm{He}$ has an industrious character to make his life better.

\section{References}

Abdul Hameed Panhwar, Sanaullah Ansari, Muhammad Hassan Khoso. (2017). Analysing Edna's Character in Chopin's Novel The Awakening through Sullivan's Theory of Inter-personal Relations. International Journal of English and Education, 6, 77- 85.

Durand, M and David H. B. (2006). Intisari Psikologi Abnormal. Yogyakarta: Pustaka Pelajar.

Hurlock, E. B. (1980). Psikologi Perkembangan: Suatu Pendekatan Sepanjang Rentang Kehidupan. Jakarta: Erlangga.

Minderop, A. (2005). Metode Karakteristik Telaah Fiksi. Jakarta: Yayasan Obor Indonesia.

Moskowitz, M. J. \& Orgel, A. L. (1969). General Psychology. Boston: Houngton Mifflin Company.

Stagner, R. (1965). Psychology of Personality. New York: McGraw-Hill Book Company.

Subhan, B. (2003). A Guide to Literary Criticism. Yogyakarta: LPPDMF. (2005). Understanding English Poetry and Prose. Yogyakarta: LPPDMF. . (2006). Literary Appreciation. Yogyakarta: LPPDMF.

Wellek, R. \& Warren, A. (1978). Theory of Literature. New York: Penguins Book. 